\title{
Phenylalanine Rich Diet (Vicia faba L.) Enhances the Expression of Dopamine Receptor D3 (DRD3) Gene in Rabbits
}

\author{
Ghada Mostafa Shebl, Hanan Ibrahim Sayed-Ahmed, Mohamed Bassuony Hamza, \\ and Ashraf Salah El-Din Haider
}

\section{ABSTRACT}

Dopamine is a neurotransmitter hormone for pleasure and reward. It is synthesized only in the brain cells of human and animals and responsible for the regulation of behavior, mood, memory, cognitive, flexible movement, the body weight, and other important functions. The Dopamine Receptor D3 (DRD3) is the most important receptor for dopamine. In this investigation, expression of DRD3 gene was studied in rabbits fed on supplemented diet of dry and fresh faba bean (Vicia faba L. Sakha 3). DRD3 gene $(\approx 1200 \mathrm{bp})$ in control and treated rabbits were PCR amplified, sequenced and aligned with reference gene (Acc. No XM_017346708.1). High genetic similarity values were detected among all sequences. DRD3 gene sequences of control, fresh and dry faba bean fed rabbits were deposited in the GenBank with accession numbers MZ714134, MZ714135 and MZ714136 respectively. Direct estimation of blood phenylalanine (Phe) amino acid indicated that feeding rabbits on dry faba bean reflected the highest level of Phe in the rabbit's blood. Quantitative RT-qPCR analysis showed that DRD3 gene was over expressed after feeding rabbits on dry faba bean form compared with feeding on green form and control. Thus, diet rich with phenylalanine like Sakha3 (dry and fresh forms) enhance gene expression of DRD3 gene. However, diet doesn't affect the DRD3 gene sequence and structure. In a conclusion, our findings indicated a direct effect of faba bean supplemented diet on increasing DRD3 expression levels which improve the life quality for human.

Keywords: Dopamine Receptor D3 (DRD3), faba bean, Oryctolagus cuniculus, RT-qPCR.

\section{INTRODUCTION}

Dopamine is a neurotransmitter hormone for pleasure and reward feeling [1], [2]. It is synthesized only in the brain cells of human and animals [3]. The blood brain barrier (BBB) allows pass of dopamine from brain to the human body, and prevents its entrance to the brain [4]. Dopamine is responsible for the regulation of behavior, mood, memory, cognitive, flexible movement, the body weight, and other important functions [5]-[7]. Decreasing the level of dopamine in the human body, causes serious diseases, for example, Parkinson's disease, Alzheimer [8]-[11], obesity [4], [12], addiction [13], [14], vitiligo [15], [16] and phenylketonuria [17]-[20]. Dopamine also affects the quality of life and health for humans and animals. Low dopamine levels result in increasing the hostility of the animal and its lack of calmness, it also affects its productivity in terms of the amount of milk produced [21], [22].

The dopamine pathway begins with phenylalanine amino acid as the main precursor for dopamine biosynthesis, which
Published Online: October 24, 2021

ISSN: 2684-5199

DOI: $10.24018 /$ ejbio.2021.2.5.297

\section{G. M. Shebl*}

Faculty of Science, Tanta University, Egypt.

(e-mail: ghada.shebl@ yahoo.com)

H. I. Sayed-Ahmed

Faculty of Science, Tanta University, Egypt.

(e-mail: hanahmed29@ yahoo.com)

M. B. Hamza

Faculty of Science, Tanta University, Egypt.

(e-mail: hamzawypedo@ yahoo.com)

A. S. E. Haider

Faculty of Science, Tanta University, Egypt.

(e-mail: ashrafhaider@ hotmail.com)

*Corresponding Author is converted to tyrosine by phenylalanine hydroxylase enzyme. Then, tyrosine is converted to LDihydroxyphenylalanine (L-Dopa) by tyrosine hydroxylase enzyme, and L-Dopa is converted to dopamine by L-Dopa decarboxylase enzyme.

The last step in dopamine pathway is binding the dopamine to its receptor in the brain, from this binding dopamine can be spread to all receptors in the body. Alternative pathway is hydroxylation of dopamine to melamine and norepinephrine, which in turn is methylated to produce epinephrine [23]-[25].

Dopamine receptors are divided into two groups; the first one is D1-Like (D1 and D5) receptors and the second group is D2-Like (D2, D3 and D4) receptors [26]-[28]. Dopamine receptors are responsible for receiving dopamine and bound with it after its production inside the brain and it, also responsible for its transmission and distribution to the entire body by transferring it as nervous signals [2], [29]-[31]. The Dopamine receptor D3 (DRD3) gene is located in the nucleus accumbens in the human brain, and any defection in this gene leads to Schizophrenia disease [32], [33]. The cycle of dopamine biosynthesis begins with the phenylalanine 
transformation process by phenylalanine hydroxylase enzyme (PAH) and ends at the binding of dopamine to DRD3 in the brain. Then dopamine comes out of the cerebral membrane to the rest of the body [34]. The Dopamine Receptor D3 (DRD3) is the most important receptor for dopamine [9], [31], [35]. Structure of DRD3 receptor is very sensitive and unique, that is made it the perfect target for a lot of drugs as a treatment for vital diseases like Schizophrenia, Depression and Parkinson's disease [36]-[38].

This investigation was aimed to evaluate the influence of direct diet with fresh and dry forms of faba bean (Sakha 3 genotype) on DRD3 levels in rabbits. DRD3 genes of rabbits were PCR amplified, sequenced, and aligned with reference gene in the GenBank.

\section{MATERIAL AND METHODS}

\section{A. Plant Materials}

Faba bean (Vicia faba L., Sakha 3 genotype) seeds were obtained from Sakha Agricultural Research Station, Kafr ElShiekh, Egypt, and planted for a whole season during (September 2018- March 2019) in suitable soil with recommended agriculture conditions. Plants were used as rabbit's food in two forms (dry and fresh) with $150 \mathrm{~g}$ feeding dose as shown in Table I.

\begin{tabular}{cccc}
\multicolumn{4}{c}{ TABLE I: FABA BEAN FEEDING EXPERIMENT DESIGN } \\
\hline \hline \multirow{2}{*}{ Rabbits } & $\begin{array}{c}\text { Faba bean } \\
\text { feed type }\end{array}$ & $\begin{array}{c}\text { Feeding } \\
\text { period }\end{array}$ & $\begin{array}{c}\text { Feeding dose } \\
(\mathrm{gm})\end{array}$ \\
\hline \hline 1 & Control & & 0.0 \\
2 & Dry & 6 months & 150 \\
3 & Fresh & & 150 \\
\hline \hline
\end{tabular}

\section{B. Animal Samples and Feeding}

New Zealand rabbits (Oryctolagus cuniculus) were available at the Faculty of Science, Tanta University. They were fed and treated according to the ethical scientific research program, license no. JACUC-SCI-TU-0126 from the Faculty of Science, Tanta University. Male rabbits 6 months aged were fed on fresh and dry beans as shown in Table I, for a period of 6 months. After feeding period, blood samples were collected from the ear vein, after sterilization with $70 \%$ ethyl alcohol. Blood samples were drawn using a medical syringe and collected in a separate tube. Rabbits were sacrificed and their brains were collected and stored for further work.

\section{Quantification of Phenylalanine Amino Acid}

Phenylalanine Assay Kit (abcam, ab83376) was used according to manufacturer protocol for direct quantification of phenylalanine amino acid levels in rabbit blood samples.

\section{PCR Amplifications of DRD3 Genes}

DRD3 gene fragments of rabbits (Oryctolagus cuniculus) were amplified, eluted, sequenced. Nucleotide sequences of treated rabbit samples were aligned and compared with control as well as with reference sequence in the GenBank.

Total genomic DNAs were purified according to manufacturer protocol of GeneJET Genomic DNA Purification Kit (K0721/ Thermo Fisher). Then, Dream Taq PCR Master Mix (2X) (K1071, Thermo Fisher. USA) was used to amplify DRD3 gene fragments. Primer design and construction was carried out using Primer BLAST Program and rabbit (Oryctolagus cuniculus) DRD3, complete cDNA (Accession Number XM_017346708.1) as reference gene. Three specific primer pairs of DRD3 were designed to cover the whole gene sequence as shown in Table II.

TABLE II: SEQUENCE FEATURES OF SPECIFIC DRD3 PRIMERS AND THE EXPECTED SIZE OF AMPLIFIED FRAGMENTS

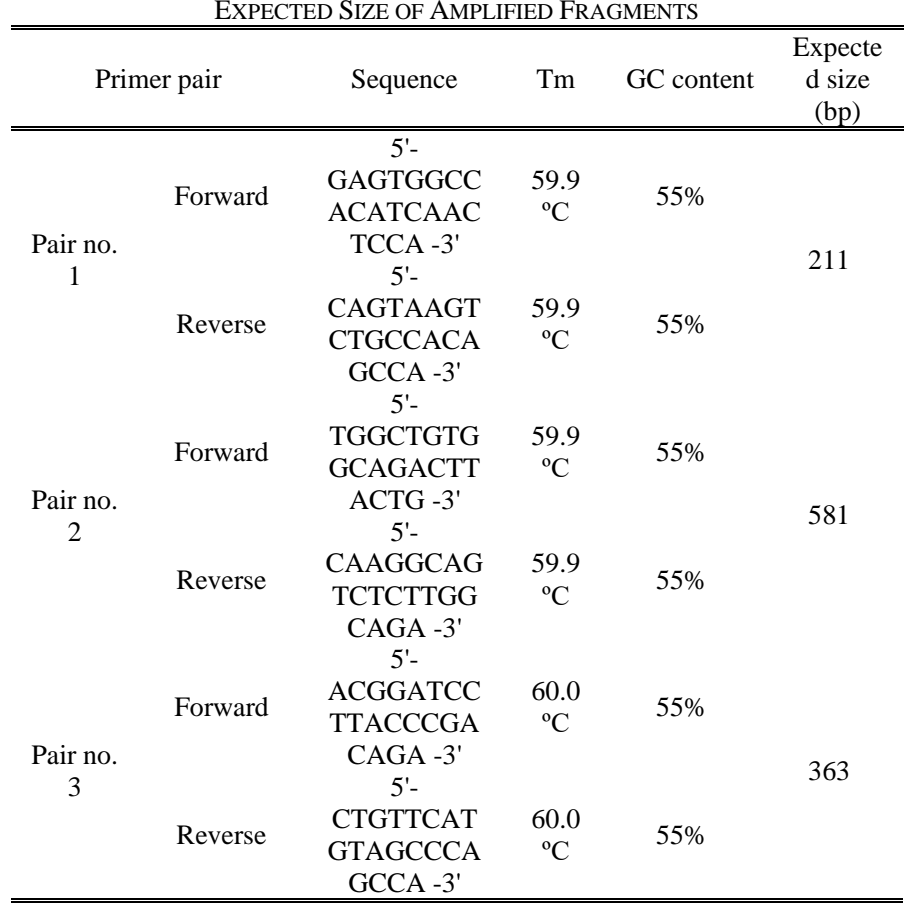

Thermal cycler (CreaCon, Holland) was used with the following conditions: 40 cycles; each cycle consisted of denaturation at $95{ }^{\circ} \mathrm{C}$ for $30 \mathrm{sec}$ followed by annealing at $37^{\circ} \mathrm{C}$ for $1 \mathrm{~min}$ and extension at $72^{\circ} \mathrm{C}$ for $2 \mathrm{~min}$. There was an initial delay for $15 \mathrm{~min}$ at $95{ }^{\circ} \mathrm{C}$ at the beginning of the first cycle and 10 min delay at $72{ }^{\circ} \mathrm{C}$ at the end of the last cycle as a post extension step. Agarose gel (1.5\%) was applied to migrate amplicons via MultiSUB Mini Horizontal Electrophoresis System with Power Pro 300 Power supply (Cleaver Scientific, UK) and imaging with Gel documentation system (OmniDOC, Cleaver Scientific, UK). Data analysis was performed using Totallab analysis software (ww.totallab.com, Ver.1.0.1).

\section{E. Nucleotide Sequencing of DRD3 Genes}

Amplified PCR fragments were purified with E.Z.N.A. ${ }^{\circledR}$ Gel Extraction Kit, (D2500-01, Omega BIO-TEK, USA). Samples were sent to Micron-Corp. Korea for sequencing with ABI PRISM®3100 Genetic Analyzer. Aligned DRD3 sequences were analyzed on NCBI website (http://www.ncbi.nlm.nih.gov/webcite) using BLAST to confirm their identity. Genetic distances and Multi Alignments were computed by Pairwise Distance method using Clustal Omegasoftware analysis (https://www.ebi.ac.uk/Tools/msa/clustalo/). The nucleotide sequences were also compared with highest homology sequences available in the GenBank.

\section{F. Quantitative RT-qPCR analysis of DRD3 genes}

Quantitative RT-qPCR was applied to detect DRD3 gene expressions after feeding rabbits on dry and fresh beans. 
DRD3 gene expression was determined using Maximas SYBR Green/Fluorescein qPCR Master Mix by Rotor-Gene Q (Qiagen, USA) using two-step cycling protocol and Glyceraldehyde-3-Phosphate as a housekeeping gene. TRIzols Reagent (15596026, Life Technologes, USA) was applied for total RNA purification from brain samples. Yield and quality of total RNA were determined Spectrophotometrically at 260 and 260/280 $\mathrm{nm}$ ratio, respectively.

\section{RESULTS}

\section{A. Levels of Phenylalanine (Phe) Amino Acid in Blood}

For evaluating direct effect of faba bean feeding dietary on phenylalanine (Phe) level in rabbits, Phe content was estimated in blood of rabbit under study. Compared with control sample, feeding on dry faba bean was superior to fresh faba bean for Phe levels. As shown in Table III, rabbits fed on $150 \mathrm{~g}$ of dry bean reflected highest increase of Phe level (311 nmol/L), compared to those fed on $150 \mathrm{~g}$ of fresh bean ( $98 \mathrm{nmol} / \mathrm{L}$ ) Control rabbits indicated a relatively low level of Phe (77 nmol/L).

TABLE III: PHENYLALANINE LEVELS IN BLOOD FOR CONTROL AND TREATED RABBITS

\begin{tabular}{cccc}
\hline \multicolumn{4}{c}{ TREATED RABBITS } \\
\hline \hline & \multicolumn{3}{c}{ Rabbit samples } \\
Phenylalanine & Control & Fresh beans & Dry beans \\
levels (nmol/L) & & $(150 \mathrm{~g})$ & $(150 \mathrm{~g})$ \\
& 71 & 98 & 311 \\
\hline \hline
\end{tabular}

\section{B. Amplification and sequences of DRD3 gene fragments}

DRD3 gene in control and faba bean fed rabbits were amplified, sequenced, and aligned with reference gene (Accession Number XM_017346708.1). Specific DRD3 amplicons with 581, 363 and 211 bp were detected for the three samples (Fig. 1).

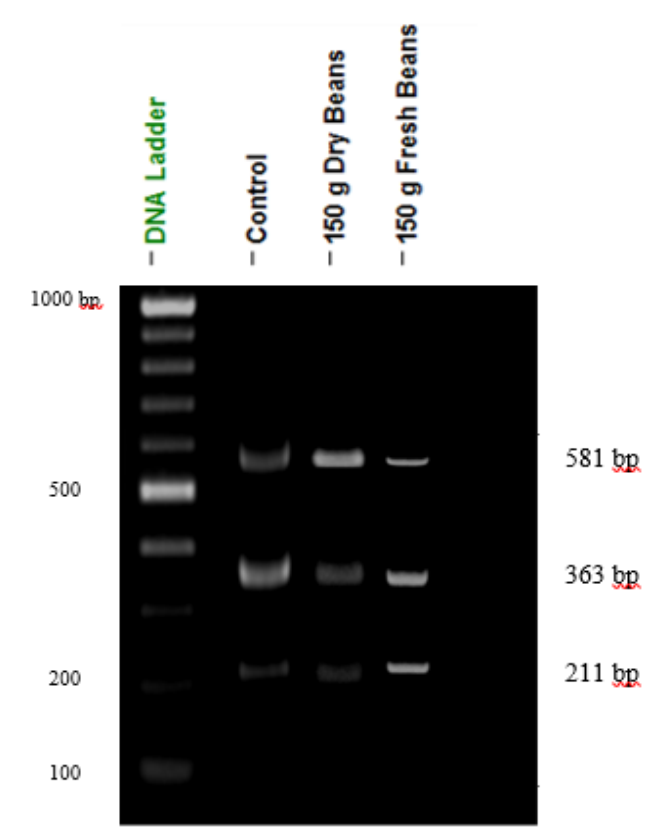

Fig. 1. Amplified PCR products of DRD3 gene with $\approx 581,363$ and $211 \mathrm{bp}$ for control and rabbits fed on $150 \mathrm{~g}$ of dry and fresh faba bean.
High genetic similarity values were detected in DRD3 gene sequences for both control and faba bean fed rabbits with reference gene sequence as shown in sequence alignment (Fig. 2) and similarity percentage (Table IV). DRD3 gene sequence for control sample reflected the highest genetic similarity with reference sequence $(98.14 \%)$. For fresh faba bean fed rabbits, the lowest genetic similarity (97.97\%) was recorded after feeding with $150 \mathrm{~g}$ faba bean. Nucleotide sequences of dry bean fed rabbits indicated (98.06\%) similarity with reference gene sequence. DRD3 gene sequences of control, fresh and dry faba bean fed rabbits were deposited in the GenBank with accession numbers MZ714134, MZ714135 and MZ714136 respectively.

TABLE IV: SIMILARITY OF DRD3 GENE SEQUENCES FOR ORYCTOLAGUS CUNICULUS WITH REFERENCE GENE (ACCESSION NUMBER XM_017346708.1) FROM GENBANK

\begin{tabular}{cc}
\hline \hline $\begin{array}{c}\text { Dopamine D3 Receptor Gene } \\
\text { Sequence }\end{array}$ & Similarity (\%) \\
\hline \hline $\begin{array}{c}\text { Rabbit fed on }(150 \mathrm{~g}) \text { of fresh } \\
\text { faba bean. }\end{array}$ & $97.97 \%$ \\
$\begin{array}{c}\text { Rabbit fed on (150 g) of dry faba } \\
\text { bean. }\end{array}$ & $98.06 \%$ \\
Rabbit control. & $98.14 \%$ \\
\hline \hline
\end{tabular}

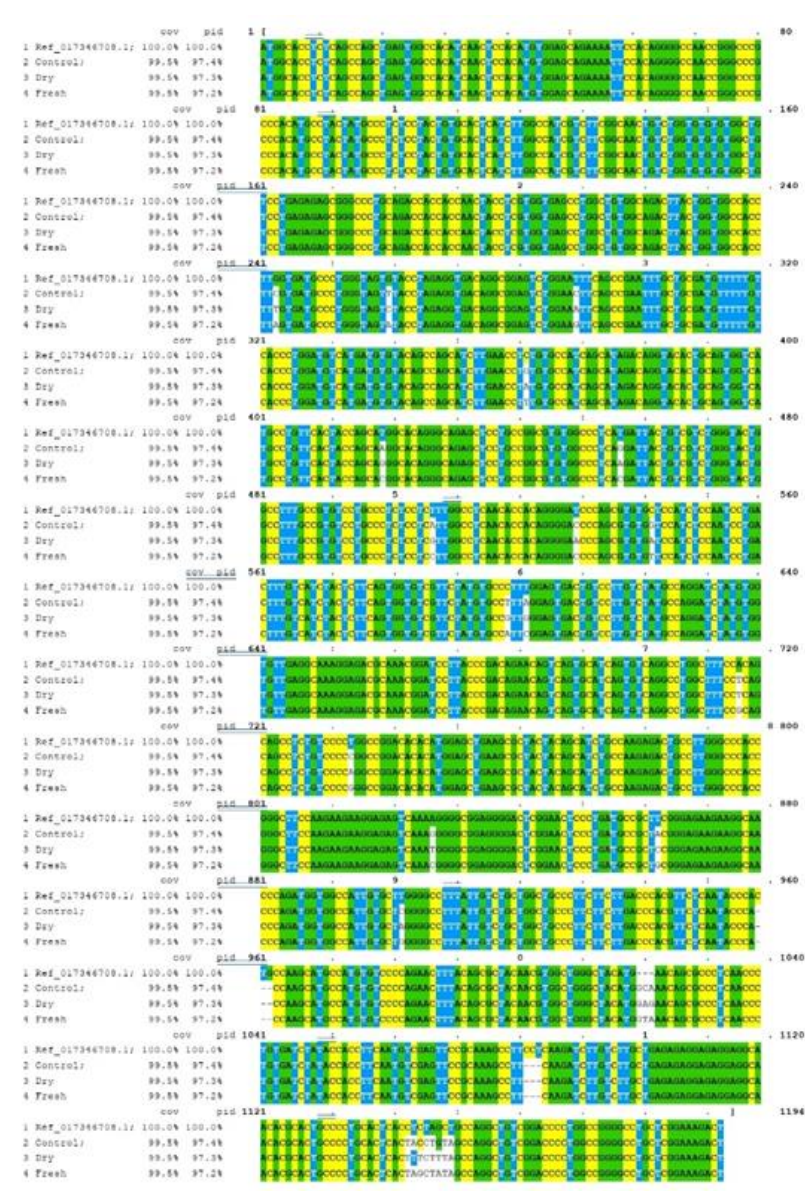

Fig. 2. Nucleotide sequence alignment of amplified DRD3 genes with reference gene (Accession Number XM_017346708.1).

\section{Expression of DRD3 gene}

Quantitative RT-qPCR was used to evaluate effect of feeding by fresh and dry faba bean on DRD3 gene expression levels. Our findings indicated overexpression of DRD3 gene as a direct influence of feeding rabbits on dry and fresh faba bean. As shown in Table V and Fig. 3, rabbits fed on $150 \mathrm{~g}$ 
of dry faba bean reflected superior increase of DRD3 gene expression level (almost three folds) compared with those fed on $150 \mathrm{~g}$ of fresh faba bean which DRD3 gene expression level with one and half fold.

TABLE V: EXPRESSION LEVELS OF DRD3 GENE

\begin{tabular}{|c|c|c|c|c|c|c|c|c|c|}
\hline \multicolumn{2}{|c|}{ Samples } & $\begin{array}{c}\text { Gene } \\
\text { being } \\
\text { Tested } \\
\text { Experime } \\
\text { ntal (TE) }\end{array}$ & $\begin{array}{c}\text { Gene being } \\
\text { Tested } \\
\text { Control } \\
\text { (TC) }\end{array}$ & $\begin{array}{l}\text { Housekeeping } \\
\text { Gene } \\
\text { Experimental } \\
(\mathrm{HE})\end{array}$ & $\begin{array}{l}\text { Housekeeping } \\
\text { Gene Control } \\
\text { (HC) }\end{array}$ & $\begin{array}{l}\Delta C t \text { values } \\
\text { for the } \\
\text { experiment } \\
\text { al }(\Delta C T E)\end{array}$ & $\begin{array}{l}\Delta \mathrm{Ct} \text { values } \\
\text { for the } \\
\text { control } \\
(\Delta \mathrm{CTC})\end{array}$ & $\begin{array}{c}\Delta \mathrm{Ct} \\
\text { Value } \\
(\Delta \Delta \mathrm{Ct})\end{array}$ & $\begin{array}{c}2^{\wedge}-\Delta \Delta \mathrm{Ct} \\
\text { (Expression fold } \\
\text { change) } \\
\text {-fold Expression level } \\
\text { in the experiment-al } \\
\text { condition the } \\
\text { expression as in the } \\
\text { control condition }\end{array}$ \\
\hline \multirow{3}{*}{ Treatments } & Control & 35.7 & 21 & 34 & 20 & 1.7 & 1 & 0.7 & 0.6 \\
\hline & $\begin{array}{l}\text { dry beans } \\
(150 \mathrm{gm})\end{array}$ & 32.2 & 21 & 32 & 20 & 0.2 & 1 & -0.8 & 1.7 \\
\hline & $\begin{array}{l}\text { fresh beans } \\
(150 \mathrm{gm})\end{array}$ & 34.7 & 21 & 33.6 & 20 & 1.1 & 1 & 0.1 & 0.9 \\
\hline
\end{tabular}

$\Delta \mathrm{Ct}$ values (Experimental) $=\mathrm{Ct}($ Tested Exp $)-\mathrm{Ct}($ Housekeeping Exp)

$\Delta \mathrm{Ct}$ values $(\mathrm{Control})=\mathrm{Ct}($ Tested Control $)-\mathrm{Ct}$ (Housekeeping Control) .

$\Delta \Delta \mathrm{Ct}$ values $=\Delta \mathrm{Ct}$ values $($ Experimental $)-\Delta \mathrm{Ct}$ values $(\mathrm{Control})$

Relative gene expression fold change $=2^{\wedge}-\Delta \Delta \mathrm{Ct}$.

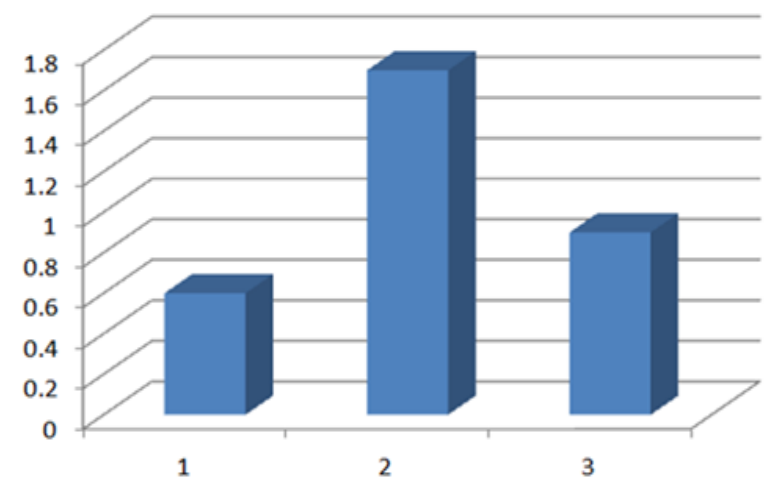

Fig. 3. Expression of DRD3 gene for three rabbit samples. 1: control, 2: rabbit fed on $150 \mathrm{gm}$ of dry beans and 3: rabbit fed on $150 \mathrm{gm}$ of fresh beans.

\section{DISCUSSION}

In this investigation, rabbits (Oryctolagus cuniculus), as a biological model, were used for Dopamine Receptor D3 (DRD3) gene sequence and expression [39], [40] indicated perfect matching dopamine biosynthesis pathway between rabbits and human and high similarity of DRD3 gene sequence between rabbits and human. Faba bean (Vicia faba L.) Sakha 3 genotype was chosen as a diet rich in phenylalanine to study the effect of different feeding conditions on DRD3 expression. Previous studies showed that faba bean plants contain high amounts of phenylalanine and phenolic amino acids [41].

Results of the present study indicated an increase of phenylalanine level in rabbit blood after fed on faba bean. This is in accordance with [42] who indicated direct influence of diet rich in phenylalanine as faba bean Sakha 3 genotype on increasing phenylalanine (Phe) amino acid in rabbit blood.

Our findings obtained by quantitative RT-qPCR reflected high increase of DRD3 gene expression level in rabbit fed on fresh and dry faba bean (one and half and three folds, respectively). This indicates a direct correlation between faba bean diet rich in phenylalanine and increasing the level of phenylalanine amino acid in the blood, which enhance DRD3 gene expression.

The cycle of dopamine biosynthesis begins with the phenylalanine transformation process by phenylalanine hydroxylase enzyme (PAH) and ends at the binding of dopamine to DRD3 in the brain. The DRD3 is the most important receptor for dopamine [31], [34], [35]. The steps of dopamine biosynthesis cycle in rabbits are the same in humans [43]. Diet rich with phenylalanine like Sakha3 (dry and fresh forms) is the main precursor for dopamine [41], [42], [44]-[46]. It is increased the gene expression of DRD3 gene.

In this investigation, DRD3 gene fragments were PCR amplified, sequenced, and aligned with reference gene. The results indicated high sequence similarity with reference gene. Thus, diet rich with phenylalanine like Sakha3 (dry and fresh forms) enhance gene expression of DRD3 gene. However, diet doesn't affect the DRD3 gene sequence and structure [47]-[51].

\section{REFERENCES}

[1] D. Martins, M. A. Mehta and D. Prata, "The "highs and lows" of the human brain on dopaminergics: Evidence from neuropharmacology," Neuroscience and Biobehavioral Reviews 80, 351-371, 2017.

[2] E. Galaj, A. H. Newman and Z. X. Xi, "Dopamine D3 receptor-based medication development for the treatment of opioid use disorder: Rationale, progress, and challenges," Neuroscience \& Biobehavioral Reviews 114, 38-52, 2020.

[3] X. Dong, Z. Liao, D. Gritsch, Y. Hadzhiev, Y. Bai, J. J. Locascio and C. H. Adler, "Enhancers active in dopamine neurons are a primary link between genetic variation and neuropsychiatric disease," Nature Neuroscience 21(10): 1482-1492, 2018.

[4] D. Benton and H. A. Young, "A meta-analysis of the relationship between brain dopamine receptors and obesity: a matter of changes in behavior rather than food addiction?" International Journal of Obesity, 40(1): S12-S21, 2016

[5] G. J. J. M. D. T. Ayano, "Dopamine: receptors, functions, synthesis, pathways, locations and mental disorders: review of literatures," Journal of Mental Disorders and Treatments 2(120): 2, 2016.

[6] C. Borwick, R. Lal, L. W. Lim, C. J. Stagg and L. Aquili, "Dopamine depletion effects on cognitive flexibility as modulated by tDCS of the dlPFC," Brain Stimulation 13(1): 105-108, 2020.

[7] K. Sreedevi, "Dopamine Dynamics in Dermatology and Behavioural Science," Journal of Addiction Science 6(2): 34-36, 2020.

[8] X. Pan, A. C. Kaminga, S. Wen, X. Wu, K. Acheampong and A. Liu, "Dopamine and dopamine receptors in Alzheimer's disease: A systematic review and network meta-analysis," Frontiers in Aging Neuroscience 11, 175, 2019.

[9] P. Yang, W. C. Knight, H. Li, Y. Guo, J. S. Perlmutter, T. L. Benzinger and J. Xu, "Dopamine D1+ D3 receptor density may correlate with Parkinson disease clinical features," Annals of Clinical and Translational Neurology 8(1): 224-237, 2021.

[10] L. F. Burbulla, and D. Krainc, "The role of dopamine in the pathogenesis of GBA1 linked Parkinson's disease," Neurobiology of Disease 132, 104545, 2019. 
[11] M. J. Armstrong and M.S. Okun, "Diagnosis and treatment of Parkinson disease: a review," Jama 323(6): 548-560, 2020.

[12] D. Matuskey, G. A. Angarita, P. Worhunsky, S. Koohsari, P. Gravel, B. Pittman and R. T. Malison, "Dopamine D2/3 receptor availability in cocaine use disorder individuals with obesity as measured by [11C] PHNO PET," Drug and Alcohol Dependence 220, 108514, 2021.

[13] R. A. Wise and M. A. Robble, "Dopamine and addiction," Annual Review of Psychology 71, 79-106, 2020.

[14] A. Sanna, L. Fattore, P. Badas, G. Corona and M. Diana, "The hypodopaminergic state ten years after: transcranial magnetic stimulation as a tool to test the dopamine hypothesis of drug addiction," Current Opinion in Pharmacology 56, 61-67, 2021.

[15] E. Reimann, K. Kingo, M. Karelson, P. Reemann, U. Loite, M. Keermann and S. Kõks, "Expression profile of genes associated with the dopamine pathway in vitiligo skin biopsies and blood sera," Dermatology 224(2): 168-176,2012.

[16] M. S. Al Abadie and D. J. Gawkrodger, "Integrating neuronal involvement into the immune and genetic paradigm of vitiligo," Clinical and Experimental Dermatology 46(4): 646-650, 2021.

[17] G. Shebl, H. Sayed Ahmed, A. Kato, H. Dawoud, M. Hamza and A. Haider, "Detection of sequence mutations in phenylalanine hydroxylase (PAH) gene isolated from Egyptian Phenylketonuria (PKU) patients," Egyptian Journal of Expertimental Biology (Botany) 15(2): 295-301, 2019.

[18] A. MacDonald, A. M. J. van Wegberg, K. Ahring, S. Beblo, A. Bélanger-Quintana, A. Burlina and S. C. Huijbregts, "PKU dietary handbook to accompany PKU guidelines," Orphanet Journal of Rare Diseases 15(1): 1-21, 2020.

[19] H. R. Shoraka, A. A. Haghdoost, M. R. Baneshi, Z. Bagherinezhad and F. Zolala, "Global prevalence of classic phenylketonuria based on Neonatal Screening Program Data: systematic review and metaanalysis," Clinical and Experimental Pediatrics 63(2): 34, 2020.

[20] A. Lopez, B. Havranek, G. A. Papadantonakis and S. M. Islam, "In silico screening and molecular dynamics simulation of deleterious PAH mutations responsible for phenylketonuria genetic disorder," Proteins: Structure, Function, and Bioinformatics 89(6): 683-696, 2021.

[21] K. P. Siju, J. F. De Backer and I. C. G. Kadow, "Dopamine modulation of sensory processing and adaptive behavior in flies," Cell and Tissue Research 1-19, 2021.

[22] M. Romanov, N. V. Dementieva, E. S. Fedorova, A. A. Krutikova, O. V. Mitrofanova, O. İ. Stanishevskaya and V. P. Terletsky, "Genetic variability of indels in the prolactin and dopamine receptor D2 genes and their association with the yield of allanto-amniotic fluid in Russian White laying hens," Journal of Agricultural Sciences 26(3): 373379,2020 .

[23] J. Britto-Júnior, N. J. Antunes, R. Campos, M. Sucupira, G. D. Mendes, F. Fernandes and G. De Nucci, "Determination of dopamine, noradrenaline, and adrenaline in Krebs-Henseleit solution by liquid chromatography coupled with tandem mass spectrometry and measurement of their basal release from Chelonoidis carbonaria aortae in vitro," Biomedical Chromatography 35(2): e4978, 2021.

[24] C. A. Marsden, "Dopamine: the rewarding years," British Journal of Pharmacology 147(S1): S136-S144, 2006.

[25] S. Yoon, S.C. Ji, J. Yang, Y. K. Kim, S. Lee, K. S. Yu and J. Y. Cho, "Ursodeoxycholic acid improves liver function via phenylalanine/tyrosine pathway and microbiome remodelling in patients with liver dysfunction,"Scientific Reports 8(1): 1-11, 2018.

[26] M. Jaber, S. W. Robinson, C. Missale and M. G. Caron, "Dopamine receptors and brain function," Neuropharmacology 35(11): 1503$1519,1996$.

[27] J. M. Beaulieu and R. R. Gainetdinov, "The physiology, signaling, and pharmacology of dopamine receptors," Pharmacological Reviews 63(1): 182-217, 2011.

[28] A. B. Ruzilawati, M. A. Islam, S. K. S. Muhamed and I. Ahmad, "Smoking Genes: A Case-Control Study of Dopamine Transporter Gene (SLC6A3) and Dopamine Receptor Genes (DRD1, DRD2 and DRD3) Polymorphisms and Smoking Behaviour in a Malay Male Cohort," Biomolecules 10(12): 1633, 2020.

[29] J. Diaz, C. Pilon, B. Le Foll, C. Gros, A. Triller, J. C. Schwartz and P. Sokoloff, "Dopamine D3 receptors expressed by all mesencephalic dopamine neurons," Journal of Neuroscience 20(23): 8677-8684, 2000

[30] T. Ott and A. Nieder, "Dopamine D2 receptors enhance population dynamics in primate prefrontal working memory circuits," Cerebral Cortex 27(9): 4423-4435, 2017

[31] Z. B. You, J. T. Gao, G. H. Bi, Y. He, C. Boateng, J. Cao and Z. X. Xi, "The novel dopamine D3 receptor antagonists/partial agonists CAB2015 and BAK4-54 inhibit oxycodone-taking and oxycodone-seeking behavior in rats," Neuropharmacology 126, 190-199, 2017.
[32] J. P. Prieto, B. González, J. Muñiz, V. Bisagno and C. Scorza, "Molecular changes in the nucleus accumbens and prefrontal cortex associated with the locomotor sensitization induced by coca paste seized samples," Psychopharmacology 1-11, 2020.

[33] A. G. Stanfill and X. Cao,"Expression of Dopamine-Related Genes in Four Human Brain Regions," Brain Sciences 10(8): 567, 2020.

[34] R. Guerrero-Bautista, A. Franco-García, J. M. Hidalgo, F. J. Fernández-Gómez, B. Ribeiro Do Couto, M. Milanés and C. Núñez, "Distinct regulation of dopamine D3 receptor in the basolateral amygdala and dentate gyrus during the reinstatement of cocaine CPP induced by drug priming and social stress," International Journal of Molecular Sciences 22(6): 3100, 2021.

[35] S. A. Bravo, C. Rangel-Barajas and B. F. Garduño, "Pathophysiology of L-Dopa Induced Dyskinesia-Changes in D1/D3 Receptors and Their Signaling Pathway," A Synopsis of Parkinson's Disease 119, 2014.

[36] P. Yang, W. C. Knight, H. Li, Y. Guo, J. S. Perlmutter, T. L. Benzinger and J. Xu, "Dopamine D1+ D3 receptor density may correlate with Parkinson disease clinical features," Annals of Clinical and Translational Neurology 8(1): 224-237, 2021

[37] N. M. Appel, S. H. Li, T. H. Holmes, and J. B. Acri, "Dopamine D3 receptor antagonist (GSK598809) potentiates the hypertensive effects of cocaine in conscious, freely-moving dogs," Journal of Pharmacology and Experimental Therapeutics 354(3): 484-492, 2015.

[38] P. Sokoloff and B. Le Foll, "The dopamine D3 receptor, a quarter century later,"European Journal of Neuroscience 45(1): 2-19, 2017.

[39] Z. X. Xi and E. L. Gardner, "Pharmacological actions of NGB 2904, a selective dopamine D3 receptor antagonist, in animal models of drug addiction,"CNS Drug Reviews 13(2): 240-259, 2007.

[40] F. Müller-Schöttle, A. Bogusz, J. Grötzinger, A. Herrler, C. A. Krusche, K. Beier-Hellwig and H. M. Beier, "Full-length complementary DNA and the derived amino acid sequence of horse uteroglobin," Biology of Reproduction 66(6): 1723-1728, 2002.

[41] M. H. Hendawey and A. M. A. Younes, "Biochemical evaluation of some faba bean cultivars under rainfed conditions at El-Sheikh Zuwayid," Annals of Agricultural Sciences 58(2): 183-193, 2013.

[42] G. Shebl, H. Sayed Ahmed, A. Kato and A. Haider, "ISSR markers of some faba bean (Vicia faba L.) genotypes in relation to phenylalanine accumulation," Egyptian Journal of. Expertimental Biology (Botany) 14(1): 73-82, 2018.

[43] P. J. Esteves, J. Abrantes, H. M. Baldauf, L. BenMohamed, Y. Chen, N. Christensen and O. T. Keppler, "The wide utility of rabbits as models of human diseases," Experimental \& Molecular Medicine 50(5): 1-10, 2018

[44] J. Hu, S. J. Kwon, J. J. Park, E. Landry, D. S. Mattinson and D. R. Gang, "LC-MS determination of L-DOPA concentration in the leaf and flower tissues of six faba bean (Vicia faba L.) lines with common and rare flower colors," Functional Foods in Health and Disease 5(7): 243$250,2015$.

[45] H. Stützel and M. S. Hanafy, "Impact of chitosan on shoot regeneration from faba bean embryo axes through its effect on phenolic compounds and endogenous hormones," Plant Archives 20(1): 2269-2279, 2020.

[46] R. H. Mekky, M. M. Thabet, C. Rodríguez-Pérez, D. M. Y. Elnaggar, E. A. Mahrous, A. Segura-Carretero and E. Abdel-Sattar, "Comparative metabolite profiling and antioxidant potentials of seeds and sprouts of three Egyptian cultivars of Vicia faba L," Food Research International 136, 109537, 2020.

[47] S. A. Fleming, A. T. Mudd, J. Hauser, J. Yan, S. Metairon, P. Steiner and R. N. Dilger, "Dietary oligofructose alone or in combination with 2 '-fucosyllactose differentially improves recognition memory and hippocampal mRNA expression," Nutrients 12(7): 2131, 2020.

[48] K. P. Skibicka, C. Hansson, E. Egecioglu and S.L. Dickson, "Role of ghrelin in food reward: impact of ghrelin on sucrose self-administration and mesolimbic dopamine and acetylcholine receptor gene expression," Addiction Biology 17(1): 95-107, 2012.

[49] M. F. Fernandes, S. Sharma, C. Hryhorczuk, S. Auguste and S. Fulton, "Nutritional controls of food reward," Canadian Journal of Diabetes, 37(4): 260-268, 2013.

[50] H. Zhang and X. F. Gu, "A study of gene expression profiles of cultured embryonic rat neurons induced by phenylalanine," Metabolic Brain Disease 20(1): 61-72, 2005.

[51] L. L. Santos, C. G. Fonseca, A. L. Starling, J. N. Januario, M. J. Aguiar, M. G. Peixoto and M. R. Carvalho,"Variations in genotype-phenotype correlations in phenylketonuria patients," Genetics and Molecular Research 9(1): 1-8, 2010. 


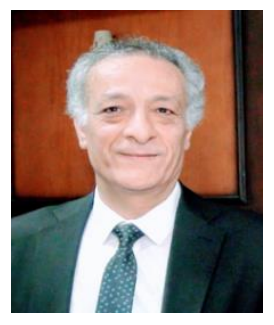

Tanta.

Member of all major committees, particularly those related to scientific research in the Faculty of Science, University of Tanta,(AGERI), (ARC) Giza.

Awarded the membership of the American Association for the Advancment of Science, January, 2001.

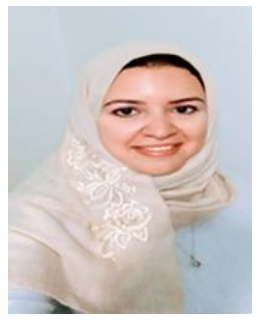

Dr. Ghada Mostafa Shebl

Tanta city, Egypt.

2007: B.Sc. degree in Microbiology.

2008: Analytical Biochemistry Diploma.

2018: Master Degree in Genetics.

2021-2022: PhD degree in Molecular Genetics.

District Manager in Pharmaceutical Company.

In 2018 in The Egyptian Society of Experimental

"ISSR markers of some faba bean (Vicia faba L.)

genotypes in relation to phenylalanine

accumulation".

In 2019 in The Egyptian Society of Experimental Biology "Detection of sequence mutations in phenylalanine hydroxylase (PAH) gene isolated from

Egyptian Phenylketonuria (PKU) patients". 